\title{
Nilai Etis Dalam Sistem Kekerabatan Jepang
}

\author{
Sri Sudarsih \\ Fakultas Ilmu Budaya \\ Universitas Diponegoro Semarang \\ E-mail: srisudarsih012005@yahoo.com
}

\begin{abstract}
Abstrak
Penelitian ini bertujuan merumuskan nilai etis dalam Sistem kekerabatan Jepang. Nilai etis tersebut tercermin dalam semangat kekeluargaan khas Jepang. Penelitian ini merupakan penelitian kualitatif bidang filsafat. Objek materialnya adalah sistem kekerabatan Jepang, sedangkan objek formalnya adalah nilai etis. Metode yang dipergunakan dalam penelitian ini adalah deskripsi dan interpretasi. Hasil yang dicapai dirumuskan sebagai berikut: sistem kekerabatan Ie dan Dozoku menjadi model pelestarian nilai-nilai tradisi yang diwariskan nenek moyang. Nilai-nilai ini bersifat universal, yaitu rasa kekeluargaan yang di dalamnya terkandung rasa cinta kasih, rasa memiliki dan kebanggaan. Kachau sebagai figur panutan posisinya central dalam melestarikan nilai ini. Nilai ini juga bisa ditranferke dalam manajemen modern dengan reinterpretasi sesuai tempat dan jamanya.
\end{abstract}

Kata kunci: nilai etis; kekerabatan ie, sistem kekerabatan, kachou

\begin{abstract}
This study aims to formulate ethical values in the Japanese kinship system. This ethical value is reflected in the Japanese family spirit. This research is a qualitative research in philosophy. The material object is the Japanese kinship system, while the formal object is an ethical value. The method used in this research is description and interpretation. The results achieved were formulated as follows: the kinship system of Ie became a model of preserving traditional values inherited from ancestors. These values are universal, namely the sense of kinship in which there is a sense of love, belonging and pride. Kachou as a role model is central in preserving this value. These values can also be transferred into modern management by reinterpretation according to place and time.
\end{abstract}

Keywords: ethical value; kindship Ie; kinship system; kachou.

1. Pendahuluan

Sistem kekeluargaan Jepang merupakan nilai tradisi yang masih mewarnai kehidupan masyarakat Jepang pada umumnya hingga kini. Ie merupakan inti dalam sistem sosial 
masyarakat Jepang. Hal ini terlihat dalam berbagai realitas dalam kehidupan masyarakat maupun kehidupan perusahaan modern.

Sistem kekeluargaan yang bersifat tradisional ditransfer dan direinterpretasi bangsa Jepang, kemudian dibawa ke masa kini hingga berhasil membawa keunggulan bangsa Jepang ke dalam alam modern walaupun Jepang sendiri sudah menyerukan meninggalkan hal-hal yang tradisional dan menuju pada modernisasi. Oleh Dohi Masataka, saat kampanye menuju modernisasi dibuat daftar tradisi yang harus segera ditinggalkan jika Jepang ingin lebih maju dan beradab (Ong, 2017:18). Namun demikian masih ada tradisi yang tetap dijalankan oleh masyarakat dan menjadi ciri khas Jepang yang justru membawa nilai lebih bagi perkembangan masyarakat.

Semangat Ie dalam masyarakat Jepang terasa dalam kehidupan seharihari. Pengamatan orang Jepang sendiri dibenarkan oleh beberapa pengamat orang luar Jepang. Kemajuan pesat yang dicapai Jepang tidak lepas dari karakter masyarakat yang memang rajin bekerja, teliti, tekun dan penuh dedikasi. Tidak jarang karyawan Jepang bekerja melebihi jam kerja atas kehendak sendiri tanpa ada yang memaksa atau memerintah tanpa upah lembur. Mereka melakukannya karena hal itu baik.

Ketika membangun, paham pragmatis memang diterapkan Jepang untuk mengejar ketertinggalan dengan negara-negara Barat, yaitu mengerahkan semua sumber daya nasional termasuk merekayasa tradisi dari tidak ada menjadi ada sejauh hal itu menguntungkan bagi modernisasi dan membawa kejayaan Jepang. Rekayasa itu misalnya semangat Jepang Bushido yang ditulis oleh Nitobe Inazo (18621933) dalam buku Bushido: The Soul of Japan mempromosikan Bushido sebagai budaya tradisional yang memiliki semangat yang perlu dijadikan panutan generasi muda. Di samping itu juga merekayasa pola hidup anak-anak melalui tokoh Ninomiya, menamamkan kepada anakanak sekolah dasar agar hidup sederhana, gemar menabung, disiplin, tekun, kerja keras, suka membantu orang lain. Caranya, pemerintah mewajibkan setiap sekolah memajang patung figur Ninomiya di halaman depan. Rekayasa bidang-bidang lain juga dilakukan seperti ketahanan nasional, budaya nasional, reformasi pola hidup, seni kerajinan yaitu dengan membentuk lembaga-lembaga nasional (Federasi Budaya Jepang) untuk mengkampanyekannya (Ong, 2017: 80230).

Ketika Jepang sudah berhasil menjadi negara industri dan mampu menciptakan sumber daya manusia yang loyal, setia pada perusahaan sebagaimana semangat kekeluargaan inilah yang diwariskan Ie di era modern. Semangat kekeluargaan Ie dijadikan energi membangun bangsa. Ini jarang terjadi di negara lain yang terkadang nilai tradisional justru dianggap sebagai budaya yang sudah using, menghambat kemajuan dan modernisasi. 


\begin{tabular}{l}
\multicolumn{4}{r}{ Semangat model Ie menjadi } \\
penting untuk dikaji $r$ dan \\
direinterpretasikan guna membangun \\
bangsa. \\
Bagaimana
\end{tabular}
mentransformasikan kepada generasi muda maupun nilai moral yang ada.

Penelitian terdahulu telah ditulis oleh Ety N. Anwar (2007) membahas mengenai ideologi keluarga luas tradisional Ie dan Kazoku Kokka sebelum PD II serta terjadi perubahan dari sistem Ie ke kaku kazoku. Sistem keluarga luas Ie merupakan sistem keluarga dan kekeluargaan pada jaman Tokugawa yang utamanya berlaku di kalangan Bushi dan bangsawan. Namun sejak Restorasi Meiji, keberadaan sistem Ie dikukuhkan dalam Undang-undang Dasar Meiji yang berlaku untuk semua lapisan masyarakat Jepang (Anwar, 2007:195).

Sementara Rima Devi (2014) membahas mengenai Struktur Keluarga Jepang Kontemporer Dalam Tiga Novel Karya Ogawa Yoko. Rima Devi membandingkan realitas dengan yang terdapat pada novel. Yang ada pada novel itu sebagai solusi keluarga alternatif bentuk keluarga yang akan datang (Devi, 2014: 77).

\section{Metode}

Penelitian ini merupakan penelitian kualitatif bidang filsafat. Metode yang dipergunakan peneliti adalah deskripsi dan interpretasi. Peneliti mendeskripsikan mengenai konsep diri orang Jepang dan revolusi masyarakat Jepang, kemudian peneliti menginterpretasikan nilai etis yang terdapat pada sistem kekerabatan pada masyarakat Jepang.

\section{Hasil dan Pembahasan}

\subsection{Pengertian Nilai Etis}

Kata nilai berasal dari Bahasa Latin valere yang diturunkan ke dalam Bahasa Inggris menjadi kata value. Valere mengandung arti: berguna, berdaya, kuat (Bagus. 2005:713). Sedangkan dalam Bahasa Inggris, value mengandung pengertian, kebenaran, kebajikan dan kekudusan. Arti lainnya sesuatu yang baik, diinginkan, kebajikan dan kekudusan (Frankena, 1972:229-230). Nilai etis dalam pembahasan dimaksudkan untuk mengetahui lebih jauh mengenai ajaran moral dalam Ie. Sesuai bidang kajian dalam Etika adalah masalah moral.

Etika adalah ilmu. Etika dan ajaran moral mempunyai tingkatan yang berbeda. Etika adalah pemikiran sistematis tentang moralitas yang dihasilkan secara langsung bukan kebaikan, melainkan suatu pengertian yang lebih mendasar dan kritis. Etika pada hakikatnya mengamati realitas moral secara kritis melalui tahapantahapan berpikir logis dan sistematis. Etika tidak memberi ajaran, melainkan memeriksa kebiasaan-kebiasaan, nilainilai, norma-norma, dan pandanganpandangan moral secara kritis. Etika menuntut pertanggungjawaban dan tidak membiarkan pendapat-pendapat moral begitu saja. Secara tidak langsung etika membawa kepada orientasi tertentu seseorang melakukan sesuatu. Ilustrasi yang cukup jelas 
perbedaan etika dengan ajaran moral ibaratnya moral adalah buku petunjuk tentang pengoperasian dengan baik sebuah sepeda motor, sedangkan etika adalah petunjuk tentang konstruksi dan cara kerja mesin sebuah sepeda motor (Suseno, 1987: 14).

Kata moral selalu mengacu pada baik-buruknya manusia sebagai manusia pada umumnya. Norma-norma moral adalah tolok ukur untuk menentukan benar salahnya sikap dan tindakan manusia dilihat dari segi baik buruknya. Bidang moral adalah bidang kehidupan manusia dilihat dari segi baik-buruknya sebagai manusia dan bukan sebagai pelaku peran tertentu.

Hal yang mendasar untuk bisa dinilai dalam masalah moral adalah kebebasan seseorang. Kebebasan yang dimaksud adalah kemampuan kita untuk menentukan sikap dan tindakan diri sendiri atau disebut kebebasan eksistensial (Suseno, 1987: 22). Bebas yang dimaksudkan adalah karena tindakan yang kita lakukan atas dasar kesadaran untuk melakukan sesuatu dengan berbagai pertimbangan bukan sekedar instingtif. Sedangkan kebebasan yang lain adalah kebebasan sosial artinya tidak ada pihak lain yang memaksa seseorang untuk melakukan atau tidak melakukan sesuatu. Jadi secara singkat dapat dirumuskan bukan seked ar bebas dari apa melainkan bebas untuk apa.

\subsection{Sistem Kekerabatan Jepang}

\subsubsection{Ie dalam sistem kekerabatan Jepang}

Sistem Ie adalah sistem keluarga dan kekeluargaan khas Jepang yang awalnya hanya berlaku di kalangan kaum Bushi dan kalangan bangsawan Jepang.

Kemudian pada masa Restorasi Meiji (1868) sistem Ie sempat dimasukkan dalam Undang-undang Dasar sehingga sistem ini berlaku juga bagi masyarakat Jepang pada umumnya. Karena nilai-nilai yang terkandung di dalamnya dianggap cocok untuk menjadi visi mengembangkan sebuah negara maka Meiji berpandangan bahwa negara kekeluargaan cocok bagi Jepang. PadaZaman Meiji (1868-1912) menerapkan negara kekeluargaan yang disebut Kazoku Kokka (Anwar, 2007: 200).

Semangat Ie dapat dikatakan telah menjadi dorongan hidup atau ellan vital dalam kehidupan sehari-hari. Setiap orang dapat mengandalkan keteladanan orang lain dan setiap atasan penuh tanggung jawab terhadap bawahannya. Keteladanan itu yang menjadi kunci keberhasilan Jepang (Nitobe, 1992: 3). Nampak jelas Ie menjadi spirit masyarakat Jepang yang telah meresap dalam proses kehidupannya.

Ie dan kazoku merupakan dua istilah untuk keluarga yang digunakan oleh masyarakat Jepang. Kata Ie merujuk pada sistem kekeluargaan tradisional dan kata kazoku mengacu pada pengertian keluarga secara umum. Namun istilah Ie maknanya lebih luas 
yaitu bermakna keluarga termasuk juga pada adat istiadat yang mengatur anggota keluarga. Ie juga merupakan suatu unit dalam kehidupan sosial dalam menjalankan bisnis keluarga. Mereka juga berupaya menjaga kelestarian dari unit Ienya secara turun menurun. Tujuan Ie adalah mempertahankan jati dirinya secara terus-menerus sekalipun yang menjadi anggota $I e$ selalu berganti. Individu yang menjadi anggota Ie tidak hanya anggota yang mempunya hubungan darah tetapi ada juga yang tidak mempunyai hubungan darah. Pewaris Ie adalah garis keturunan langsung yang mempunyai hubungan darah, yaitu anak laki-laki sulung atau disebut chounan. Saudara laki-laki kedua, ketiga, dan seterusnya, saudara perempuan jika sudah menikah harus meninggalkan Ienya. Kecuali adik lakilaki bungsu sekalipun sudah menikah dipertahankan tinggal di Ie asalnya. Hal ini didasarkan pada alasan jika kachou sewaktu-waktu meninggal dan pewarisnya belum mampu menggantikannya maka adik terkecil inilah yang diangkat menjadi kachou untuk sementara waktu (Devi, 2014:7980). Kachou memiliki kedudukan yang penting karena sebagai penentu kebijakan dalam keluarga Ie.

Tiga ciri khas Ie adalah suatu unit dasar kehidupan masyarakat Jepang. Pertama, memiliki zaisan. Zaisan adalah harta benda sebagai warisan. Kedua, sosen suuhai, yaitu melaksanakan upacara pemujaan terhadap arwah leluhur Ie secara berkala. Ketiga, melestarikan myoji, yaitu mengedepankan kesinambungan nama keluarga dan kelangsungan keturunan (Torigoe Hiroyuki dalam Anwar, 2007: 198). Karena itu Ie harus berlanjut tidak boleh berhenti walaupun kachou tidak memiliki anak laki-laki sebagai pewaris atau bahkan 'tidak memiliki keturunan darah". Maka penerus Ie dapat dilimpahkan kepada salah seorang anggota keluarga atau kerabat yang bukan keturunan langsung dari kachou, misalnya keponakan ataupun anak angkat. Atau bisa juga Ie diambil alih istri dari kachou yang meninggal, bahkan pembantu asal memiliki kesadaran rasa memiliki Ie tersebut (Takeda Chosu dalam Anwar, 2007: 198).

Ada norma yang harus dipatuhi seluruh anggota $I e$, yang diwarisi dari jaman Tokugawa hingga akhir Perang Dunia II (Fukutake dalam Anwar, 2007:199).

1. Kepentingan Ie diletakkan diatas kepentingan pribadi

2. Kachou berwenang menetukan atas segala aspek penting dalam kehidupan keluarga seperti aspek ekonomi, hak waris dan pemujaan leluhur.

3. Hubungan bapak dan anak dijunjung tinggi daripada hubungan suami-istri.

4. Chounan sebagai pewaris utama dan menduduki kachou dan hakhak lain yang penting dari anakanak yang lainnya.

5. Harkat dan martabat laki-laki lebih diutamakan daripada wanita. 
6. Hubungan perkawinan lebih diutamakan sebagai penyatuan hubungan Ie.

7. Martabat keluarga utama (honke) lebih diutamakan dari keluarga cabang (bunke).

Beberapa alternatif pengganti kachou tersebut sangat memungkinkan keberlangsungan sistem keluarga tradisional khas Ie tetap berlangsung. Namun bagi keluarga dengan aset warisan berupa tanah pertanian memiliki tantangan yang berat. Di satu sisi jumlah keluarga makin banyak dan kebutuhan meningkat, sementara jumlah tanah pertanian semakin berkurang sehingga hasilnyapun berkurang. Pada keluarga Ie yang basis warisannya adalah usaha perdagangan dan industri maka peluang mengembangkan usahanya makin lebar. Penghasilan bisa lebih besar sehingga kesejahteraan anggota keluarga Ie pun terpenuhi.

Melihat kenyataan ini, bisa dilihat sistem keluarga Ie saat ini dalam tantangan menghadapi perkembangan gaya hidup akibat pergeseran tatanan sosial kemasyarakatan di negara industri. Fenomena yang terjadi banyak anggota $I e$ yang mulai meninggalkan Ienya, lebih memilih membentuk keluarga kecil atas dasa pertimbangan kebutuhan ekonomi.

\subsubsection{Ie dalam Tantangan Jaman}

Kemajuan Jepang dalam membangun negara industri telah menggeser tatanan dan gaya hidup masyarakat Jepang. Para generasi muda berpendidikan tinggi banyak yang mulai meninggalkan pekerjaan yang diturunkan orangtuanya dan memilih pekerjaan lain didunia industri. Mereka yang pindah ke kota terutama mereka yang bukan pewaris Ie. Mereka ada yang pindah pekerjaan secara musiman, tetapi ada juga yang pindah dan membentuk keluarga baru di kota. Tapi banyak juga, bersama pasangan hidupnya mereka pindah bekerja di sektor industri dan membentuk keluarga kecil. Keluarga kecil yang lebih sesuai namanya batih yang hubungan kekeluargaanya lebih berorientasi pada hubungan suami-istri (Devi, 2014: 79). Keluarga batih yang anggotanya hanya terdiri dari ayah, ibu dan anak, tidak banyak aturan yang mengikat sebagaimana keluarga tradisinal Ie. Bentuk keluarga model baru ini dirasakan lebih adil bagi seluruh anggota keluarga. Suami-istri mendapat kesempatan yang sama dalam bekerja. Mereka punya kemandirian dalam memilih jalan hidupnya sesuai arah dan tujuan hidupnya sendiri. Maka banyak anggota masyarakat yang memilih jalan hidup dengan membentuk keluarga kecil atau justru hidup sendiri tanpa menikah.

Namun bagi pewaris Ie yang mampu mengelola modal telah melahirkan kaum kapitalis zaibatsu, yaitu para pemilik modal yang memiliki perusahaan-perusahaan besar yang mampu menguasai pasar. Bahkan perusahaan-perusahaan yang awalnya dikelola oleh keluarga terbatas, kini telah mendunia tidak hanya di Jepang. Perusahaan jenis ini menggunakan 
sistem kekeluargaan Ie untuk mengontrol modalnya oleh karena itu kedudukan penting dalam perusahaan diserahkan pada anggota keluarga Ie. Bahkan semangat kekeluargaan bisa ditanamkan kepada karyawankaryawannya. Tentu saja hal ini diimbangi dengan tanggung jawab pimpinan perusahaan untuk menyejahterakan mereka, sebagaimana kewajiban kachou yang bertanggungjawab kepada anggota keluarga Ie-nya. Perasaan menjadi bagian dari keluarga ini merupakan semangat yang sudah dimiliki setiap karyawan.

Nilai lain dalam semangat kekeluargaan ini adalah kesetiaan. Kesetiaan merupakan inti dalam semangat kekeuargaan. Bagaimana bisa ada keluarga jika tanpa kesetiaan dalam semangat keluarga.

\subsection{Nilai Etis Dalam Kekerabatan Jepang}

Pertanyaan mendasar dalam pembahasan ini adalah kenapa sistem kekeluargaan Ie menjadi keluarga khas di Jepang. Banyak nilai positif dengan sistem kekeluargaan model Jepang ini. Di antaranya, terjaganya keberlangsungan keturunan sekaligus mewarisi nilai-nilai luhur nenek moyang karena adat-istiadat terjaga.

Ikatan kekeluargaan sesama saudara terpelihara kuat karena ada yang memimpin seorang kachou. Seorang kachou bisa menjadi figur panutan para anggota keluarganya, artinya sebagai figur konkret mempermudah transfer nilai-nilai moral kepada anggota keluarga Ie. Bagi anggota keluarga yang baru lahir dapat belajar langsung di lingkungan keluarga tempat tinggalnya. Karena dengan belajar langsung, anak melihat dan meniru perilaku orang dewasa, kemudian membiasakan melakukannya. Pola meniru perilaku figur ini dijadikan model kampanye mereformasi budaya Jepang. Figur konkret inilah yang dijadikan model metodologi kampanye Jepang ketika membangun negaranya menuju negara modern. Ukuran moral yang sifatnya abstrak ditinggalkan Jepang. Untuk itu program pembangunan yang dikampanyekan diwujudkan dalam rumusan konkret. Misalnya kampanye merubah masyarakat agar pola hidup hemat, dengan melarang bentuk sesaji yang boros. Di Indonesia kampanye yang konkret juga berhasil "dua anak cukup". Tetapi program kampanye yang abstrak sulit dipahami masyarakat sehingga sulit berhasil. "Gerakan disiplin nasional" tidak berhasil karena abstrak tidak ada figur yang dicontoh.

Keluarga khas Jepang dalam sistem Ie setidaknya bisa menjadi model cara memelihara dan mewariskan nilai-nilai moral yang termuat dalam tradisi.

Pada akhirnya, jika nilai ini sudah diresapi dibenak setiap individu maka dapat membentuk karakter. Jika karakter sudah terbentuk maka setiap perilaku akan menceminkan nilai-nilai yang dihayati sejak kecil yang 
ditanamkan di lingkungan keluarga. Keluarga menjadi basis menanamkan nilai-nilai moral hingga membentuk karakter individu. Hal ini akan dijabarkan dan diimplementasikan dalam tindakan di manapun dan kapanpun. Termasuk ketika anggota Ie mengelola harta kekayaan atau mengelola perdagangan di tingkat yang lebih besar dan luas. Nilai moral Ie tersebut bisa direinterpretasikan dalam manajemen modern. Nilai keadilan mereka wujudkan dalam kesejahteraan karyawan perusahaan modern oleh para pimpinan perusahaan. Pihak manajemen perusahaan secara imperatif kategoris telah melakukan kewajibannya sebagaimana kewajiban kachou dalam keluarga Ie.

Sed angkan untuk penghormatan kepada para leluhur setiap saat diadakan upacara sesaji oleh anggota keluarga Ie yang dipimpin kachou. Ini merupakan kewajiban moral yang menimbulkan rasa solidaritas sesama anggota keluarga. Mereka berpandangan leluhur ini akan menjadi dewa yang akan memberikan kemakmuran kepada mereka.

Bagi orang Jepang, perusahaan tempatnya bekerja itu adalah uchi, artinya (bagian) dalam atau berarti juga rumah. Uchi hanya berlaku bagi orang Jepang yang merasa bahwa orang lain di sekitarnya juga menjadi bagian keluarganya. Orang Jepang tidak memiliki konsep dosa. Tindakan yang dilakukan didorong uchi. Misalnya jika tetangga membersihkan rumah, maka dia juga merasa wajib ikut agar rumahnya juga bersih. Kalau rumahnya tidak bersih, dia malu. Rasa malu karena tidak sama dan seirama dengan orang lain inilah yang menjadi inti dari uchi. Orang Jepang untuk menyesuaikan diri dengan temannya sudah menjadi kebiasaan, kalau tidak, dia akan malu. Tapi perasaan malu hanya ada jika orang sekitar adalah uchinya. Orang Jepang yang ada di Indonesia tidak akan malu walau rumahnya tetangga lebih bersih. Hal ini karena tetangga tersebut bukan uchinya (Rosidi, 2009: 16-20).

Kemampuan

mereinterpretasikan nilai-nilai kekeluargaan $I e$ bisa menjadi keunggulan dalam persaingan budaya yang mendasari Jepang berkembang menjadi Negara Industri. Justru dengan munculnya kaum pemodal menunjukkan kemampuan dalam mengelola modal usaha ekonominya.

Sistem Ie, masih memandang kaum perempuan atau istri sebagai warga yang terpinggirkan. Kaum perempuan belum bahkan tidak memiliki hak yang sama dengan kaum laku-laki. Nilai keadilan sosial belum bisa diwujudkan khusus untuk kaum wanita. Sedangkan bagi anggotanya tidak ada kebebasan individu. Mereka tetap mengikuti yang telah ditetapkan kachou. Walaupun kebebasan mutlak tidak ada dalam keluarga apapun namun setiap keluarga terikat kontrak 
karena keluarga adalah kontrak saling mengikatkan diri dengan pasangannya. Tujuan keluarga sendiri adalah untuk mengupayakan kebahagiaan bersama dengan cara saling melengkapi. Budaya Jawa menyebut "mbangun bebrayan agung".

Tugas kachou juga makin berat karena memikul tanggung jawab menyejahterakan seluruh anggota keluarganya. Beban ekonomi dengan meningkatnya kebutuhan hidup makin tinggi. Pola hidup karena perkembangan jaman juga berubah maka kebutuhan untuk menyejahterakan anggota makin berat. Di samping itu, jika pimpinan keluarga tidak bisa menjadi panutan maka anggoa keluarganya kehilangan ukuran moral yang konkret sehingga dapat menimbulkan kekacauan tatanan dalam keluarga besarnya jika tidak ada figur pengganti.

Nilai lain dalam semangat kekeluargaan ini adalah kesetiaan. Kesetiaan merupakan inti dalam semangat kekeluargaan. Bagaimana bisa ada keluarga jika tanpa kesetiaan dalam semangat keluarga.

\section{Kesimpulan}

Nilai moral yang terkandung dalam sistem keluarga Ie memiliki nilai yang universal sebagai pengikatnya. Sebagaimana dalam keluarga pada umumnya baik keluarga kecil maupun besar yaitu moral kesetiaan, loyalitas dan kebanggaan masing-masing anggota keluarga.
Oleh karena niai moral sifatnya universal, maka tak heran jika nilainilai tersebut bisa diterjemahkan dalam managemen modern sebagai landasan yang kuat untuk mengembangkan rasa saling memiliki sebagaimana dalam keluarga. Apabila nilai yang demikian itu hilang dalam sebuah keluarga maka makna keluarga itupun hilang juga.

Kachou sebagaimana kepala keluarga pada umumnya diwajibkan mewujudkan keadilan kepada seluruh anggota keluarga. Keadilan itu dalam upaya mewujudkan kesejahteraan dan kebahagiaan semua anggota keluarga. Begitu juga setiap anggota keluarga memiliki kewajiban menjaga tradisi Ie nya yaitu dengan semangat $u c h i$.

Pada saat ini sistem keluarga Ie khas Jepang masih dipraktekan sebagian dari masyarkat Jepang sebagai pelestarian tradisi. Perlu reinterpretasi sistem kekeluargaan $I e$ di tengahtengah perkembangan jaman yang makin individualis dan serba instan.

Penelitian lebih jauh dan mendalam mengenai sistem kekeluargaan Ie hanya ada di Jepang perlu dilakukan dalam upaya menemukan nilai-nilai moral di dalamnya.

\section{Referensi}

Anwar, Ety N. 2007. Ideologi Keluarga Tradisional Ie dan Kozoku Kokka. Jurnal Wacana: Jurnal Ilmu Pengetahuan Budaya. Vol. 9, No. 2 tahun 2007 (http://wacana.ui.ac.id/index.php /wjhi/article/view/212). Diakses pada tanggal 5 Juni 2020. 
Bagus, Lorens. 2005, Kamus Filsafat.

Jakarta: Gramedia Pustaka

Utama.

Bakker, Anton Bakker dan Charis

Zubair. 1990. Metodologi

Penelitian Filsafat.

Yogyakarta: Kanisius.

Devi, Rima. 2014. Struktur Keluaga

Jepang Kontemporer Dalam

Tiga Novel Karya Ogawa

Yoko. Jurnal Lingua Culture.

Vol. 8, No. 2 tahun 2014

(https://journal.binus.ac.id/index .php/Lingua/article/view/446).D

iakses pada tanggal 5 Juni

2020 .

Frankena, William. K., 1972, The

Encyclopedia of Philosophy,

Volume Seven, Editor in

Chief: Paul Edwards. New

York: Macmillan Publishing

Co., Inc. \&The Free Pess.

Nitobe, Inazo. 1992. Bushido, Kepribadian Bangsa Jepang, Suatu ulasan tentang alam pikiran Jepang, alih bahasa Haryono. Semarang: Yayasan Karti Sarana.

ONG, Susy. 2017. Seikatzu Kaizen, Reformasi Pola Hidup Jepang. Jakarta: PT Elex Media Komputindo.

Rosidi, Ajip. 2009. Orang Dan Bambu Jepang, Catatan seorang Gaijin). Jakarta: Pustaka Jaya.

Suseno, Franz Magnis. 1987. Etika Dasar, Masalah-masalah Pokok dalam Filsafat Moral, Yogyakarta: Kanisius. 